\title{
Towards a governance assessment framework for geospatial data: A policy coherence evaluation of the geospatial data policy in Flanders
}

\author{
Casiano Flores, Cesar ${ }^{\mathrm{a}}$ (corresponding author), Chantillon, Maxim ${ }^{\mathrm{a}}$ and Crompvoets, Joep ${ }^{\mathrm{a}}$ \\ cesar.casiano@kuleuven.be, maxim.chantillon@kuleuven.be,joep.crompvoets@kuleuven.be
}

${ }^{\text {a }}$ Public Governance Institute, KU Leuven, Leuven, Belgium

\begin{abstract}
Governance Assessment Frameworks allow the identification of implementation bottlenecks and they can propose answers to the identified challenges. However, no assessment framework has been developed to 1) understand how governance factors can affect the development and use of geospatial data (GD) and 2) to allow comparison across different governance contexts. Previous research proved that GD and governance are highly interrelated. Understanding the relevance of policy coherence, and aiming to address the aforementioned gap, we propose the Coherence Assessment Framework for Geospatial Data (CAFGD). CAFGD objective is to contribute to the GD governance literature from an implementation perspective. CAFGD is based on two existing frameworks: 1) the Framework to Support Institutional Arrangements in Geospatial Information Management (FSIAGIM) (Crompvoets and Ho, 2017, 2019) and 2) the Governance Assessment Tool (GAT) (Bressers et al., 2016a). CAFGD uses as governance dimensions the seven structural instruments of FSIAGIM, classified under the hierarchy, market and network governance approach and uses as evaluative quality coherence from GAT. In order to demonstrate the application of CAFGD, we have selected the region of Flanders in Belgium to analyze its GD policy coherence. Our results conclude that coherence is higher in the instruments related to hierarchy. Therefore, coherence is higher among the public sector actors when comparing with the private sector actors. The relation to this sector corresponds to the market and network instruments.
\end{abstract}

Keywords: Governance Assessment Framework, Policy Coherence, Geospatial Data, Flanders

\section{Introduction}

A framework can be defined as a set of assumptions, concepts, values and practices that construct a manner of viewing a particular aspect of reality (J. Hinkel, P. Bots, and M. Schlüter, unpublished manuscript; Binder et al., 2013). It can also be seen as an aid for decisionmaking (Knol et al., 2010). Based on these benefits, in the last years, there has been an increase in the development of Governance Assessment Frameworks.

Governance Assessment Frameworks are important because they allow the identification of implementation bottlenecks and they can propose answers to the identified challenges (Casiano Flores, 2017). Among the most recent Governance Assessment Frameworks are the Fit-for-purpose Governance Assessment Framework (Casiano Flores et al., 2020), the OECD Multi-level Governance Framework (Akhmouch and Correia, 2016), the Management Transition Framework (PahlWostl et al., 2010), the Land Governance Assessment Framework (World Bank, 2015) and the Governance Assessment Tool (Bressers et al., 2016a). However, no assessment framework has been specifically developed to understand how governance factors can affect the development and use of geospatial data (GD) while allowing comparison across different governance contexts. The closest is the SPOTES framework for geospatial governance in the context of e-government. However, this framework has been developed to understand only the geospatial governance in the context of e-government in Tanzania (Ngereja et al., 2018).

GD and governance are highly interrelated. While the proper use of GD can support the development of effective strategies to address key global and complex challenges such as climate change (Crompvoets and Ho, 2017), GD establishment, sustainable usage and 
maintenance face numerous governance challenges. GD is no longer a technological activity only. Its creation and use deals with a large number of organizations, institutions and legal factors that are part of a governance context (Ran and Nedovic-Budic, 2016; Vandenbroucke et al., 2011). GD has a complex structure and is characterized by a high level of heterogeneity in data formats and models. Therefore, several processes that include the use of GD require improvement including the discovery of models, data harmonization and data analysis (Kliment et al., 2014).

Fewer attention has been paid to the impact of coordination efforts on the process of sharing GD with different users (Vancauwenberghe et al., 2014). In general, studies of GD from a governance perspective are still rare (Chantillon et al., 2017b; Sjoukema et al., 2017), as well as studies of the impact of GD from both an integral and a multi-level governance perspective (Ran and Nedovic-Budic, 2016).

Against this background, we propose a framework that can help both 1) to understand how governance factors can affect the development and use of geospatial data (GD) and 2) to allow comparison across different governance contexts. This paper is a first step towards the construction of such a framework. This first step is focused on the governance quality of coherence. Coherence from a governance perspective can be defined as the degree to which the various elements of the governance context are strengthening rather than weakening each other (Bressers et al., 2016b). Coherence has been identified as a key governance quality that can help both to reach the Sustainable Development Goals and to accelerate our response to important global challenges (OECD, 2019a, 2019b) such as climate change, pandemics, urbanisation, etc. Many of these challenges, including climate challenge require collaboration across different policy sectors (horizontal coherence) and among the different governmental levels (vertical coherence) (OECD, 2019b).

Our proposed framework named Coherence Assessment Framework for Geospatial Data (CAFGD), aims to contribute to the literature of governance from an implementation perspective. Implementation of regulations from a governance perspective has received little attention (Van Rijswick et al., 2014). We have aligned CAFGD with governance literature and it is part of the hierarchy, market network governance logic (Bouckaert et al., 2010; Meuleman, 2014; Pahl-Wostl, 2019). Since CAFGD is context sensitive, it is aligned with other frameworks that consider contextual factors too (Ansell and Gash, 2008; Bressers and Kuks, 2013; Pahl-Wostl, 2009; Van Rijswick et al., 2014; Thiel and Egerton, 2011).

CAFGD applies a systematization process, since this is a way of sorting through complexity, allowing a framework for practitioners to consider the context and dynamics of their particular settings (O'Toole, 2004). The quality of coherence is semi-normative. This characteristic allows the assessment for single and comparative cases. Semi-normative means that the normative content of the quality is both derived and dependent on the importance and urgency of the implementation of policies and projects under assessment (Bressers et al., 2016b). Examples of assessments based on the semi-normative qualities of the governance context can be found in single and comparative studies at the regional level i.e. Puebla and Tlaxcala region in Mexico, North Rhine-Westphalia in Germany, the Brittany region in France, Flanders region in Belgium, Twente region in the Netherlands (Bressers et al., 2016b; Casiano Flores et al., 2019; Casiano Flores and Crompvoets, 2020) and at the national level i.e. Rwanda, Kenya and Romania (Casiano Flores et al., 2020; Tan et al., 2019; Vinke-de Kruijf et al., 2015).

\section{Methodology for the creation of the Framework}

As one of the main challenges of policy coherence research is conceptual fragmentation, which undermines theoretical advancements, our proposed framework responds to the call of Trein et al (2020) to link existing concepts instead of developing new ones (Trein et al., 2020). Therefore, the CAFGD is based on two existing frameworks: 1) the Framework to Support Institutional Arrangements in Geospatial Information Management (FSIAGIM) (Crompvoets and Ho, 2017, 2019) and 2) the Governance Assessment Tool (GAT) (Bressers et al., 2016a).

FSIAGIM and GAT frameworks are context sensitive. Both have a solid theoretical background (Bouckaert et al., 2010; Bressers and Kuks, 2013). FSIAGIM is the result of understanding the relevance of institutional arrangements in geospatial information management (Crompvoets and Ho, 2017, 2019).

FSIAGIM underpins institutional arrangements in the public sector via three governance mechanisms: hierarchies, markets, and networks. These mechanisms rely on specific instruments, which can be structural. Crompvoets \& Ho (2017) argue that "[i]nstitutional 
arrangements may be realized by creating new or changing existing structures or management forms within the government" (Crompvoets and Ho, 2017: 146). The framework includes seven structural instruments in the context of national institutional arrangements. Since the framework was developed under the hierarchy, market and network governance logic, the instruments were also classified considering such an approach (Crompvoets and Ho, 2019). Table 1 presents this classification.

\begin{tabular}{|c|c|c|c|}
\hline Instruments & Hierarchy & Market & Network \\
\hline Structural & $\begin{array}{c}\text { S1. Establishment of coordinat- } \\
\text { ing functions or entities }\end{array}$ & S4. Regulated markets & $\begin{array}{c}\text { S5. Systems for information ex- } \\
\text { change and sharing }\end{array}$ \\
\hline & $\begin{array}{c}\text { S2. Reshuffling division of } \\
\text { competences }\end{array}$ & & $\begin{array}{c}\text { S6. Entities for collective deci- } \\
\text { sion- making }\end{array}$ \\
\hline & $\begin{array}{c}\text { S3. Establishment of a legal } \\
\text { framework }\end{array}$ & & S7. Partnerships \\
\hline
\end{tabular}

Tab. 1. Classification of structural instruments into the hierarchy, market and network governance (Crompvoets and Ho, 2019)

To transform FSIAGIM into a governance assessment framework, it requires a governance evaluative criterion that can help to identify and assesses the factors that support the effective delivery, use and creation of GD. In this respect, GAT and its focus on coherence from a governance perspective can provide important insights to fill this gap. GAT has already proven strengths in understanding governance contexts when implementing different types of projects (Boer de et al., 2016; Lordkipanidze et al., 2019). The framework is based on the Contextual Interaction Theory (CIT) (Bressers et al., 2015) and sees governance as a context for decisionmaking and implementation. Governance can be both supportive and restrictive for those implementation processes. Governance here assumes the existence of five dimensions: a multiplicity of actors, levels, goals, instruments and different means that can be applied (Bressers et al., 2016b). The questions around each of the dimensions allow a systematic assessment of the governance context. In the case of coherence, GAT understands it through the question: Are the elements in the dimensions of governance supporting, rather than contradicting, each other? (Bressers et al., 2016b). Due to the governance nature of CAFGD, the structural governance aspects of FSIAGIM are considered the governance dimensions. These are listed below (Crompvoets and Ho, 2019):

- S1. Establishment of coordinating functions or entities. This instrument refers to the existence of coordination bodies with clearly allocated resources and responsibilities. These bodies must have as the main function the coordination of geospatial data as well as the monitoring and control of the specific goal.
- S2. Reshuffling of competencies. This instrument refers to the flexibility inside institutions that are part of the context of geospatial information management. This involves the centralization and decentralization of geospatial information management.

- S3. Establishment of a legal framework. This instrument refers to the construction or adoption of a regulatory framework for geospatial information at the different governmental levels. Among the included legislation is that related to digital information, open data, freedom of information, intellectual property rights or the protection of personal data.

- S4. Regulated markets. This instrument refers to the creation of regulated markets where there are incentives for the creation and development of geospatial information. These markets are commonly created by the government and depend on users and providers.

- S5. Systems for information exchange and sharing. This instrument refers to the creation and maintenance of systems that allow information exchange, information flow, information accessibility and better organization. Geoportals are a good example.

- S6. Entities for collective decision-making. This instrument refers to the existence of strategic decision-making boards composed by senior officials from different organizations but within the policy domain of geospatial information management. This collective group is expected to set and control a collective geospatial management strategy. 
- S7. Partnerships. This instrument refers to the creation and stimuli of public partnerships for geospatial management with other government actors, business sectors and non-governmental organizations.

\section{Results: CAFGD and its application}

CAFGD is the result of considering the seven structural instruments as the dimensions to be evaluated by the governance quality of coherence. By looking at coherence we assume that policy implementation can fail due to the lack of elements that should be considered and/or due to the lack of connection among those elements (Pahl-Wostl et al., 2013). Table 2 presents the integration of the instruments from FSIAGIM with the governance quality of coherence from GAT to create CAFGD as well as its operationalization. The operationalization presents the range of conditions within each cell. The final assessment of each quality can be assessed as high, moderate, or low. Based on previous application of GAT, when the support is assessed as low, the governance context restricts the development or use of GD, when it is moderate is neutral and when it is high, the governance context is supportive.

\begin{tabular}{|c|c|c|c|c|}
\hline Instruments & Governance Quality & \multicolumn{3}{|c|}{ Operationalization } \\
\hline Structural & Coherence & Coherence - High & $\begin{array}{c}\text { Coherence - } \\
\text { Moderate }\end{array}$ & Coherence - Low \\
\hline $\begin{array}{l}\text { S1. Establish- } \\
\text { ment of coordi- } \\
\text { nating func- } \\
\text { tions or entities }\end{array}$ & $\begin{array}{l}\text { Do the different in- } \\
\text { volved actors in the } \\
\text { coordination body } \\
\text { working together? }\end{array}$ & $\begin{array}{l}\text { The involved actors in } \\
\text { the coordination body } \\
\text { working together }\end{array}$ & $\begin{array}{l}\text { Some of the involved } \\
\text { actors in the coordi- } \\
\text { nation body working } \\
\text { together }\end{array}$ & $\begin{array}{l}\text { The involved actors } \\
\text { in the coordination } \\
\text { body are not working } \\
\text { together }\end{array}$ \\
\hline $\begin{array}{l}\text { S2. Reshuffling } \\
\text { division of } \\
\text { competences }\end{array}$ & $\begin{array}{l}\text { Do the different ac- } \\
\text { tors involved in geo- } \\
\text { spatial management } \\
\text { trust each other? }\end{array}$ & $\begin{array}{l}\text { The different actors in- } \\
\text { volved in geospatial } \\
\text { management trust each } \\
\text { other }\end{array}$ & $\begin{array}{l}\text { Few actors involved } \\
\text { in geospatial manage- } \\
\text { ment trust each other }\end{array}$ & $\begin{array}{l}\text { The actors involved } \\
\text { in geospatial manage- } \\
\text { ment do not trust } \\
\text { each other }\end{array}$ \\
\hline $\begin{array}{l}\text { S3. Establish- } \\
\text { ment of a legal } \\
\text { framework }\end{array}$ & $\begin{array}{l}\text { Do the different legal } \\
\text { frameworks for geo- } \\
\text { spatial management } \\
\text { support each other to } \\
\text { promote open data, } \\
\text { freedom of infor- } \\
\text { mation and personal } \\
\text { data protection? }\end{array}$ & $\begin{array}{l}\text { The legal frameworks } \\
\text { for geospatial manage- } \\
\text { ment support each } \\
\text { other to promote open } \\
\text { data, freedom of infor- } \\
\text { mation and personal } \\
\text { data protection }\end{array}$ & $\begin{array}{l}\text { There are some over- } \\
\text { laps or contradictions } \\
\text { among the legal } \\
\text { frameworks for geo- } \\
\text { spatial management } \\
\text { when promoting open } \\
\text { data, freedom of in- } \\
\text { formation and per- } \\
\text { sonal data protection }\end{array}$ & $\begin{array}{l}\text { There are important } \\
\text { overlaps or contradic- } \\
\text { tions among the legal } \\
\text { frameworks for geo- } \\
\text { spatial management } \\
\text { when promoting open } \\
\text { data, freedom of in- } \\
\text { formation and per- } \\
\text { sonal data protection }\end{array}$ \\
\hline $\begin{array}{l}\text { S4. R } \\
\text { mark }\end{array}$ & $\begin{array}{l}\text { Does the market in- } \\
\text { centivizes different } \\
\text { actors to create and } \\
\text { develop geospatial in- } \\
\text { formation? }\end{array}$ & $\begin{array}{l}\text { The market incentiv- } \\
\text { izes different actors to } \\
\text { create and develop geo- } \\
\text { spatial information }\end{array}$ & $\begin{array}{l}\text { The market restricts } \\
\text { some actors to create } \\
\text { and develop geospa- } \\
\text { tial information }\end{array}$ & $\begin{array}{l}\text { The market restricts } \\
\text { most actors to create } \\
\text { and develop geospa- } \\
\text { tial information }\end{array}$ \\
\hline $\begin{array}{l}\text { S5. Systems for } \\
\text { information ex- } \\
\text { change and } \\
\text { sharing }\end{array}$ & $\begin{array}{l}\text { Is the participation of } \\
\text { different actors in the } \\
\text { information shared } \\
\text { platform taken into } \\
\text { consideration? }\end{array}$ & $\begin{array}{l}\text { The participation of } \\
\text { different actors in the } \\
\text { information shared } \\
\text { platform is taken into } \\
\text { consideration }\end{array}$ & $\begin{array}{l}\text { The participation of } \\
\text { only some actors in } \\
\text { the information } \\
\text { shared platform is } \\
\text { taken into considera- } \\
\text { tion }\end{array}$ & $\begin{array}{l}\text { Only the participation } \\
\text { of a minority of ac- } \\
\text { tors in the infor- } \\
\text { mation shared plat- } \\
\text { form is taken into } \\
\text { consideration }\end{array}$ \\
\hline $\begin{array}{l}\text { S6. Entities for } \\
\text { collective deci- } \\
\text { sion- making }\end{array}$ & $\begin{array}{l}\text { Does the collective } \\
\text { decision-making en- } \\
\text { tity take into consid- } \\
\text { eration all the rele- } \\
\text { vant actors? }\end{array}$ & $\begin{array}{l}\text { The collective deci- } \\
\text { sion-making entity } \\
\text { takes into consideration } \\
\text { all the relevant actors }\end{array}$ & $\begin{array}{l}\text { The collective deci- } \\
\text { sion-making entity } \\
\text { takes into considera- } \\
\text { tion only some rele- } \\
\text { vant actors }\end{array}$ & $\begin{array}{l}\text { The collective deci- } \\
\text { sion-making entity } \\
\text { takes into considera- } \\
\text { tion a minority of rel- } \\
\text { evant actors }\end{array}$ \\
\hline $\begin{array}{l}\text { S7. Partner- } \\
\text { ships }\end{array}$ & $\begin{array}{l}\text { Do the partnerships } \\
\text { create social capital } \\
\text { to favor geospatial } \\
\text { management? }\end{array}$ & $\begin{array}{l}\text { The partnerships create } \\
\text { social capital to favor } \\
\text { geospatial management }\end{array}$ & $\begin{array}{l}\text { The partnerships pro- } \\
\text { vide limited benefits } \\
\text { that favor geospatial } \\
\text { management }\end{array}$ & $\begin{array}{l}\text { The partnerships do } \\
\text { not create social capi- } \\
\text { tal that favors geo- } \\
\text { spatial management }\end{array}$ \\
\hline
\end{tabular}

Tab. 2. Coherence Assessment Framework for Geospatial Data (CAFGD) 
In order to demonstrate the relevance of CAFGD, we have selected for its application the Belgian northern region of Flanders. Over the years, and starting in the 1990's, Flanders has developed a geospatial policy and related GD infrastructure. The answers that resulted from the assessment are based on fieldwork conducted in the region of Flanders by the authors in the last years and the revision of the most relevant documents on GD. Those document include, among others, legal texts establishing the governance structure and the main building blocks structuring the geospatial data infrastructure of the Flemish Region (Agency Digital Flanders, n.d.; Agency Information Flanders, n.d., n.d., n.d., n.d., n.d., n.d.; Flemish Government, 2016; Flemish Regional Parliament, 2009a, 2009b, 2015, 2004, 2007).

Hereunder the governance qualities of coherence will be assessed for the seven structural instruments.

- S1. Establishment of coordinating functions or entities. Until end 2016, the Steering Group Geospatial Data Infrastructure (GDI) Flanders, together with the GDI Council and the Working Group GDI Flanders existed within the Agency Information Flanders. Since 2016, the Steering Group, and the related Council and Working Group, were merged with other groups into the Steering Group Flemish Information and ICT Policy. This new Steering Group provides advice to the responsible minister and allows that the different actors can together shape the geospatial policy, while also considering other policy areas. It provides the necessary forum to communicate and discuss geospatial requirements, especially relevant for those working within the same public administration level. Technical topics are discussed by field experts, under supervision of the Steering Group. This ensures a close connection between the overarching policy and the technical requirements (Geopunt Vlaanderen, n.d.).

\section{Assessment: High}

- S2. Reshuffling division of competences: A combination of legal frameworks and active collaboration exists, whereby the different (leading) actors are aware that in order to have a successful geospatial policy, trust is required. Also, the long-term collaboration and the successful implementation of geospatial projects, has led to an increased trust between the different actors. Examples of such successful geospatial projects are Geopunt (Geopunt Vlaanderen, n.d.), the main geospatial platform of Flanders including all available public data, services and metadata, the KLIP Platform (Agency Information Flanders, n.d.), allowing the digital exchange of cable and pipe information, and the standardized address structure (Agency Information Flanders, n.d.).

\section{Assessment: High}

- S3. Establishment of a legal framework: Within the Flemish region, different legal frameworks exist for open data, freedom of information and personal data protection. Although tensions and difficulties can exist, there is an overall agreement that the different legal frameworks support each other. Also, whenever modifications are required to the legal frameworks, the impact on the existing legal frameworks is assessed in advance. In 2018 most of the legal frameworks for those three domains were merged into the Bestuursdecreet, a general government decree (Flemish Regional Parliament, 2018).

\section{Assessment: High}

- S4. Regulated markets: Active collaboration exists between private and public sector actors in the field of GD. This collaboration ranges from specific projects to more long-term collaboration. Examples are, among others, the already referred KLIP Platform and the Meeting Day Digital Flanders (Agency Digital Flanders, n.d.). Nevertheless, it remains a traditional public-private relationship, whereby the private sector would like to have a further evolution towards more innovative agreements, e.g. including the use of specific data in exchange for other types of data (Chantillon et al., 2017a).

\section{Assessment: Moderate}

- S5. Systems for information exchange and sharing: As mentioned above, the main system for information exchange and sharing is Geopunt (Geopunt Vlaanderen, n.d.). Furthermore, also other platforms exists, such as the already referred to KLIP Platform (Agency Information Flanders, n.d.). Those 
platforms were developed and are maintained by the Agency Digital Flanders, with the input from both public and private sector actors. Also, users have the possibility to participate in the improvement of the platforms. However, the decision to modify platforms based on input received from users is in the hands of the Agency Digital Flanders and the Steering Group Flemish Information and ICT Policy. Also, private sector actors might be confronted with more obstacles to participate than public sector actors.

\section{Assessment: Moderate}

- S6. Entities for collective decision-making: The public sector actors are part of GDIFlanders and the above referred to Steering Group Flemish Information and ICT Policy. The situation is however different for the relation with private sector actors. Those actors are not part of this governance arrangement, except via expert positions (Geopunt Vlaanderen, n.d.). The private sector has however developed a number of initiatives together with public sector actors, whereby the above referred to KLIP Platform is the most well-known and important common activity (Agency Information Flanders, n.d.).

\section{Assessment: Moderate}

- S7. Partnerships: As mentioned in relation to S1, the Steering Group GDI Flanders was merged with other groups into the Steering Group Flemish Information and ICT Policy. This governance redesign has led to a stronger connection of the geospatial policy to other policy domains. Also, other partnerships are created when it comes to specific geospatial projects. This does not only lead to direct outcomes related to the activities undertaken, but also to limited indirect outcomes that favor the geospatial management, such as an increased level of trust and knowledge of potential future collaboration partners (Chantillon et al., 2017a, 2020).

\section{Assessment: Moderate}

\section{Conclusion}

The application of CAFGD has allowed us to understand better the governance of GD from an implementation perspective. CAFGD demonstrates that the dimensions of governance in terms of coherence are supporting the geospatial data policy in the Belgian region of Flanders. This support ranges from moderate to high. Table 3 below summarizes the results of this assessment.

\begin{tabular}{|c|c|c|}
\hline \multicolumn{3}{|c|}{ Structural Instruments } \\
\hline Hierarchy & Market & Network \\
\hline $\begin{array}{l}\text { S1: Establishment } \\
\text { of coordinating } \\
\text { functions or enti- } \\
\text { ties: High }\end{array}$ & $\begin{array}{l}\text { S4: Regulated } \\
\text { markets: } \\
\text { Moderate }\end{array}$ & $\begin{array}{l}\text { S5. Systems for } \\
\text { information ex- } \\
\text { change and shar- } \\
\text { ing: Moderate }\end{array}$ \\
\hline $\begin{array}{l}\text { S2: Reshuffling } \\
\text { division of com- } \\
\text { petences: High }\end{array}$ & & $\begin{array}{l}\text { S6. Entities } \\
\text { for collective } \\
\text { decision- mak- } \\
\text { ing: Moderate }\end{array}$ \\
\hline $\begin{array}{l}\text { S3: Establish- } \\
\text { ment of a legal } \\
\text { framework: } \\
\text { High }\end{array}$ & & $\begin{array}{l}\text { S7. Partner- } \\
\text { ships: } \\
\text { Moderate }\end{array}$ \\
\hline
\end{tabular}

Tab. 3. Results of the Governance Assessment

Based on these results we can conclude that coherence is the highest in the structural instruments related to hierarchy. The reforms in the last decade have helped to decrease fragmentation in the GD governance context. Therefore, coherence is high among the public sector actors, but there is still room for improvement when it comes to the coherence in relation to private sector actors. The relation to this sector corresponds to the structural market and network instruments. It is therefore advised that policymakers focus their effort on those instruments in order to improve coherence in the GD policy implementation. A higher focus on the participation of citizens and service users, via dedicated platforms, could lead to an increase of coherence in the GD policy implementation. An example is the cocreation platform of the City of Leuven (Belgium). It allows citizens and others to co-create the city policy (City of Leuven, n.d.). Such a platform could be relevant for the regional public administration as well.

Regarding CAFGD, as mentioned before, we consider its development a first step in the development of a more integral assessment tool that can allow us to evaluate other key governance qualities such as extent, flexibility and intensity. These qualities are part of the GAT and have proved to be highly relevant to analyze and to compare across different governance contexts in 
developed and developing countries (Bressers et al., 2016a; Casiano Flores et al., 2019).

Finally, by developing CAFGD and applying it, we exemplify its use and demonstrate its relevance to understand coherence issues in the GD policy implementation. We invite other scholars to use our framework to evaluate GD policy implementation in other governance contexts. We encourage them to use their results and to contrast them with ours to compare across different governance contexts. Table 2 can be used to facilitate such comparison as it contains the operationalization of the governance quality of coherence. These comparisons will help 1) to increase our understanding on the role of governance factors when developing and using GD. This better understanding can help the development of theoretical knowledge that can support the creation of theorical propositions and typologies on GD policy coherence when considering governance factors and 2) to refine and develop further CAFGD, by including other relevant factors that need to be considered when assessing other national and regional cases. This could also imply a refinement of the low-moderate-high scale in terms of its operationalization.

\section{References}

Agency Digital Flanders: Digitaal Vlaanderen, n.d.

Agency Digital Flanders: Trefdag Digitaal Vlaanderen, n.d.

Agency Information Flanders: Basiskaart Vlaanderen (GRB), n.d.

Agency Information Flanders: CRAB-decreet en uitvoeringsbesluiten, n.d.

Agency Information Flanders: Kabel- en Leidinginformatieportaal (KLIP), n.d.

Agency Information Flanders: Organisatie, n.d.

Agency Information Flanders: Wat is het GIPOD?, n.d.

Agency Information Flanders: Wat is het GRB?, n.d.

Akhmouch, A. and Correia, F. N.: The 12 OECD principles on water governance - When science meets policy, Util. Policy, doi:10.1016/j.jup.2016.06.004, 2016.

Ansell, C. and Gash, A.: Collaborative Governance in Theory and Practice, J. Public Adm. Res. Theory, 18(4), 543-571, doi:10.1093/jopart/mum032, 2008.

Binder, C., Hinkel, J., Bots, P. and Pahl-Wostl, C.: Comparison of Frameworks for Analyzing Socialecological Systems, Ecol. Soc., 18(4),
doi:DOI:10.5751/es-05551-180426, 2013.

Boer de, C., Vinke-de Kruijf, J., Özerol, G. and Bressers, H.: Collaborative Water Resource Management: What makes up a supportive governance system?, Environ. Policy Gov., 26, 229-241, doi:10.1002/eet.1714, 2016.

Bouckaert, G., Peters, B. G. and Verhoest, K.: The Coordination of Public Sector Organizations. Shifting Patterns of Public Management, Palgrave Macmillan UK, Hampshire., 2010.

Bressers, H. and Kuks, S.: Water governance regimes: Dimensions and dynamics, Int. J. Water Gov., 1(1), 133-156, doi:10.7564/12-IJWG1, 2013.

Bressers, H., Bressers, N., Browne, A., Furusho, C., Lajeunesse, I., Larrue, C., Özerol, G., Ramos, M.-H., Stein, U., Tröltzsch, J. and Vidaurre, R.: Benefit of governance in drought adaptation: Governance assessment guide, edited by H. Bressers and N. Bressers, DROP project European Union. [online] Available from: http://doc.utwente.nl/97103/, 2015.

Bressers, H., Bressers, N. and Larrue, C., Eds.: Governance for Drought Resilience, Springer International Publishing., 2016a.

Bressers, H., Bressers, N., Kuks, S. and Larrue, C.: The Governance Assessment Tool and its Use, in Governance for Drought Resilience, edited by $\mathrm{H}$. Bressers, N. Bressers, and C. Larrue, Springer International Publishing., 2016b.

Casiano Flores, C.: Context Matters: Water Governance Assessment of the Wastewater Treatment Plant Policy in Central Mexico, University of Twente, Enscehde., 2017.

Casiano Flores, C. and Crompvoets, J.: Assessing the Governance Context Support for Creating a Pluvial Flood Risk Map with Climate Change Scenarios: The Flemish Subnational Case, ISPRS Int. J. GeoInformation, 9(7), 460, doi:10.3390/ijgi9070460, 2020.

Casiano Flores, C., Özerol, G., Bressers, H., Kuks, S., Edelenbos, J. and Gleason, A.: The state as a stimulator of wastewater treatment policy: a comparative assessment of three subnational cases in central Mexico, J. Environ. Policy Plan., doi:10.1080/1523908X.2019.1566060, 2019.

Casiano Flores, C., Tan, E., Buntinx, I., Crompvoets, J., Stöcker, C. and Zevenbergen, J.: Governance assessment of the UAVs implementation in Rwanda under the fit-for-purpose land administration approach, Land use policy, 99, 104725, doi:10.1016/j.landusepol.2020.104725, 2020.

Chantillon, M., Simonofski, A., Tombal, T., Kruk, R., Crompvoets, J., de Terwangne, C., Habra, N., Snoeck, M. and Vanderose, B.: FLEXPUB Public e-Service Strategy - Report WP2. FLEXPUB - Work package 2 Baseline Measurement, Leuven., 2017a. 
Chantillon, M., Crompvoets, J. and Peristeras, V.: The Governance Landscape of Geospatial E-Services-The Belgian Case, ISPRS Int. J. Geo-Information, 6(9), 282, doi:10.3390/ijgi6090282, 2017b.

Chantillon, M., Kruk, R., Simonofski, A., Tombal, T., Crompvoets, J., de Terwangne, C., Habra, N., Snoeck, M. and Vanderose, B.: FLEXPUB Public e-Service Strategy - Report WP5. FLEXPUB - Work package 5 Case Studies, Leuven., 2020.

City of Leuven: Co-create Leuven! - Your idea for the future of Leuven., n.d.

Crompvoets, J. and Ho, S.: To develop a framework and guidelines in support of national institutional arrangements in geospatial information management for Member States. United Nations Committee of Experts on Global Geospatial Information Management. [online] Available from: https://lirias.kuleuven.be/handle/123456789/602841, 2017.

Crompvoets, J. and Ho, S.: Developing a Framework for National Institutional Arrangements in Geospatial Information Management, in Sustainable Development Goals Connectivity Dilemma, edited by A. Rajabifard, pp. 141-161, CRC Press., 2019.

Flemish Government: Besluit van de Vlaamse Regering Houdende de Oprichting van het Intern Verzelfstandigd Agentschap Informatie. Vlaanderen, de Bepaling van Diverse Maatregelen voor de Ontbinding Zonder Vereffening van het AGIV, de Regeling van de Overdracht van de Activitei, Flemish Government, Brussels., 2016.

Flemish Regional Parliament: Decreet Houdende de Oprichting van het Publiekrechtelijk Vormgegeven Extern Verzelfstandigde Agentschap "Agentchap voor Geografische Informatie Vlaanderen," Flemish Regional Parliament, Brussels., 2004.

Flemish Regional Parliament: Decreet van 27 april 2007 betreffende het hergebruik van overheidsinformatie, Flemish Parliament, Brussels., 2007.

Flemish Regional Parliament: Decreet Betreffende de Geografische Data-Infrastructuur Vlaanderen, Flemish Regional Parliament, Brussels., 2009a.

Flemish Regional Parliament: Decreet Betreffende het Centraal Referentieadressenbestand, Flemish Regional Parliament, Brussels., 2009b.

Flemish Regional Parliament: Decreet van 15 juni 2015 tot wijziging van het decreet van 27 april 2007 betreffende het hergebruik van overheidsinformatie en het decreet van 18 juli 2008 betreffende het elektronische bestuurlijke gegevensverkeer, Flemish Regional Parliament, Brussels., 2015.

Flemish Regional Parliament: Decreet Bestuursdecreet, 2018.
Geopunt Vlaanderen: GDI-Vlaanderen, n.d.

Geopunt Vlaanderen: Over Geopunt, n.d.

Kliment, T., Gálová, L., Ďuračiová, R., Fencík, R. and Kliment, M.: Geospatial Information Relevant to the Flood Protection Available on The Mainstream Web, Slovak J. Civ. Eng., 22(1), 9-18, doi:10.2478/sjce-20140002, 2014.

Knol, A. B., Briggs, D. J. and Lebret, E.: Assessment of complex environmental health problems: Framing the structures and structuring the frameworks, Sci. Total Environ., 408(14), 2785-2794, doi:10.1016/j.scitotenv.2010.03.021, 2010.

Lordkipanidze, M., Bressers, H. and Lulofs, K.: Governance assessment of a protected area: the case of the Alde Feanen National Park, J. Environ. Plan. Manag., 62(4), 647-670, doi:10.1080/09640568.2018.1441014, 2019.

Meuleman, L.: Governance Frameworks, in Global Environmental Change, edited by B. Freedman, pp. 885-901, Springer Science+Business Media, Dordrecht., 2014.

Ngereja, Z. R., Liwa, E. J. and Buberwa, F.: ADOPTION OF GEOSPATIAL GOVERNANCE IN THE CONTEXT OF E-GOVERMENT IN TANZANIA: ADDRESSING BOTTLENECKS IN SPATIAL DATA INFRASTRUCTURE DEVELOPMENT, ISPRS - Int. Arch. Photogramm. Remote Sens. Spat. Inf. Sci., XLII-4/W8, 163-170, doi:10.5194/isprs-archives-XLII-4-W8-163-2018, 2018 .

O'Toole, L. J.: The Theory-Practice Issue in Policy Implementation Research, Public Adm., 82(2), 309329, doi:10.1111/j.0033-3298.2004.00396.x, 2004.

OECD: Governance as an SDG Accelerator, OECD Publishing, Paris., 2019a.

OECD: Policy Coherence for Sustainable Development 2019, OECD Publishing, Paris., 2019b.

Pahl-Wostl, C.: A conceptual framework for analysing adaptive capacity and multi-level learning processes in resource governance regimes, Glob. Environ. Chang., 19(3), 354-365, doi:http://dx.doi.org/10.1016/j.gloenvcha.2009.06.001, 2009.

Pahl-Wostl, C.: The role of governance modes and meta-governance in the transformation towards sustainable water governance, Environ. Sci. Policy, 91, 6-16, doi:10.1016/j.envsci.2018.10.008, 2019.

Pahl-Wostl, C., Holtz, G., Kastens, B. and Knieper, C.: Analyzing complex water governance regimes: the Management and Transition Framework, Environ. Sci. Policy, 13(7), 571-581, doi:http://dx.doi.org/10.1016/j.envsci.2010.08.006, 2010 . 
Pahl-Wostl, C., Conca, K., Kramer, A., Maestu, J. and Schmidt, F.: Missing links in global water governance: A processes-oriented analysis, Ecol. Soc., 18(2), doi:10.5751/ES-05554-180233, 2013.

Ran, J. and Nedovic-Budic, Z.: Integrating spatial planning and flood risk management: A new conceptual framework for the spatially integrated policy infrastructure, Comput. Environ. Urban Syst., 57, 6879, doi:10.1016/j.compenvurbsys.2016.01.008, 2016.

Van Rijswick, M., Edelenbos, J., Hellegers, P., Kok, M. and Kuks, S.: Ten building blocks for sustainable water governance: An integrated method to assess the governance of water, Water Int., 39(5), 725-742, doi:10.1080/02508060.2014.951828, 2014.

Sjoukema, Jaap-Willem; Bregt, Arnold; Crompvoets, J.: Evolving Spatial Data Infrastructures and the Role of Adaptive Governance, Evol. Spat. Data Infrastructures Role Adapt. Gov., 6(8), 2017.

Tan, E., Casiano Flores, C., Crompvoets, J., Pattyn, V. and Serene, H.: Deliverable 7.4 Application of Governance and Capacity Assessment Models, Leuven., 2019.

Thiel, A. and Egerton, C.: Re-scaling of Resource Governance as institutional change: The case of water governance in Portugal, J. Environ. Plan. Manag., 54(3), 383-402, doi:10.1080/09640568.2010.507936, 2011.

Trein, P., Biesbroek, R., Bolognesi, T., Cejudo, G. M., Duffy, R., Hustedt, T. and Meyer, I.: Policy Coordination and Integration: A Research Agenda, Public Adm. Rev., doi:10.1111/puar.13180, 2020.

Vancauwenberghe, G., Dessers, E., Crompvoets, J. and Vandenbroucke, D.: Realizing Data Sharing: The Role of Spatial Data Infrastructures, in Open Government, pp. 155-169, Springer New York, New York, NY., 2014.

Vandenbroucke, D., Crompvoets, J., Dessers, E., Janssen, K., Vancauwenberghe, G. and Vanhaverbeke, L.: SDI at Work -The Flood Mapping Case., 2011.

Vinke-de Kruijf, J., Kuks, S. and Augustijn, D.: Governance in support of integrated flood risk management? The case of Romania, Environ. Dev., 16(December), 104-118, doi:10.1016/j.envdev.2015.04.003, 2015.

World Bank: Land Governance Assessment Framework / Welcome, [online] Available from: http://web.worldbank.org/WBSITE/EXTERNAL/EXT DEC/EXTRESEARCH/EXTPROGRAMS/EXTARDR /EXTLGA/0,,contentMDK:23381112 pagePK:641684 45 piPK:64168309 theSitePK:7630425,00.html (Accessed 3 September 2018), 2015.

Author, F. and Author, S.: The test article, International Journal of GIScience., 12, 135-147, https://doi.org/10.1234/56789, 2019.
Author, O., Author, T. and Author, F.: More test articles, Transactions in GIS., 35, 13-28, https://doi.org/10.2345/67890, 2020. 